\title{
Two Different Endothelin B Receptor Subtypes Mediate Contraction of the Rabbit Saphenous Vein
}

\author{
Mariko Nishiyama', Kayoko Moroi', Li-Hua Shan ${ }^{1}$, Masao Yamamoto ${ }^{2}$, Chikahisa Takasaki ${ }^{3}$, \\ Tomoh Masaki ${ }^{4}$ and Sadao Kimura ${ }^{1}$

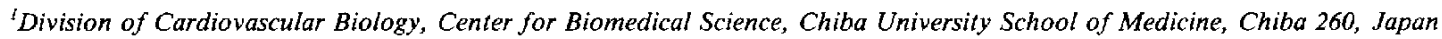 \\ ${ }^{2}$ Research Laboratories, Nippon Chemiphar Co., Ltd., Misato 341, Japan \\ ${ }^{3}$ Department of Chemistry, Faculty of Science, Tohoku University, Sendai 980, Japan \\ ${ }^{4}$ Department of Pharmacology, Faculty of Medicine, Kyoto University, Kyoto 606, Japan
}

Received January 24, 1995 Accepted March 31, 1995

\begin{abstract}
To study endothelin receptor subtypes that mediate venous smooth muscle contraction, effects of some endothelin receptor agonists and antagonists on the rabbit lateral saphenous vein were examined and compared with those on the saphenous artery. In the artery, endothelin (ET)-1 elicited concentration-dependent contractions, while selective $\mathrm{ET}_{\mathrm{B}}$-receptor agonists, IRL1620 (Suc-[Glu $\left.{ }^{9}, \mathrm{Ala}{ }^{11,15}\right]_{\mathrm{ET}}$ $1(8-21)$ ) and sarafotoxin $6 \mathrm{c}(\mathrm{S} 6 \mathrm{c})$ had almost no effect. The ET-1-induced responses shifted in parallel to the right by BQ-123 (cyclo (-D-Trp-D-Asp-Pro-D-Val-Leu-)), an ET $_{\mathrm{A}}$-receptor antagonist, or PD142893 (Ac-D-Dip-Leu-Asp-Ile-Ile-Trp), an $\mathrm{ET}_{\mathrm{A}} / \mathrm{ET}_{\mathrm{B}}$-receptor antagonist, indicating the involvement of the $\mathrm{ET}_{\mathrm{A}}$ receptor in this response. In the saphenous vein, not only ET-1 and ET-3, but also $\mathrm{ET}_{\mathrm{B}}$-receptor agonists, IRL1620, S6c and [Glu $]$ sarafotoxin 6b ([Glu $]$ S6b), produced concentration-dependent, BQ-123-insensitive contractions. PD142893 did not affect the ET-1-induced contraction, but it shifted greatly the IRL1620-induced concentration-response curve in parallel to the right. The major components of ET-3-, S6c- and [Glu']S6b-induced contractions were resistant to PD142893. These results indicate that two different vasoconstrictive $\mathrm{ET}_{\mathrm{B}}$-receptor subtypes, $\mathrm{ET}_{\mathrm{B} 1}$ (sensitive to IRL1620 and PD142893) and $\mathrm{ET}_{\mathrm{B} 2}$ (insensitive to IRL1620 and PD142893), are located on the smooth muscle of the saphenous vein.
\end{abstract}

Keywords: Endothelin, Sarafotoxin, Saphenous artery and vein (rabbit), Endothelin receptor, Endothelin receptor antagonist

Since the original discovery of endothelin (ET)-1 in the culture media of porcine aortic endothelial cells (1), its effects on the cardiovascular system have been intensely studied, because this natural peptide of vascular origin has highly potent vasoconstrictor activity. Three endogenous endothelin isopeptides, ET-1, ET-2 and ET-3 (2), and at least two distinct endothelin receptors, $\mathrm{ET}_{\mathrm{A}}$ and $\mathrm{ET}_{\mathrm{B}}(3)$, are currently known. The $\mathrm{ET}_{\mathrm{A}}$ receptor has higher affinities for ET-1 and ET-2 than for ET-3 (4), and the $E T_{B}$ receptor is non-selective towards all three endothelin isopeptides (5). Until recently, it was generally assumed that in vascular tissues, the vasoconstrictor effects of endothelins are mediated by $\mathrm{ET}_{\mathrm{A}}$ receptors on the smooth muscle cells (6), and that $\mathrm{ET}_{\mathrm{B}}$ receptors on the endothelial cells mediate the release of prostacyclin and endothelium-derived relaxing factor (EDRF) induced by endothelins $(7,8)$.

However, considerable accumulated evidence has indi- cated that a non- $\mathrm{ET}_{\mathrm{A}}$ or $\mathrm{ET}_{\mathrm{B}}$-like receptor on vascular smooth muscle is also involved in endothelin-induced vasoconstriction in some blood vessels, especially in veins or some particular vascular beds, e.g., the rabbit saphenous vein, the rabbit jugular vein, the rat renal vascular bed and the porcine pulmonary vein $(9-14)$. Most of these suggestions came from studies with selective $\mathrm{ET}_{\mathrm{A}}$-receptor antagonists, such as BQ-123 (cyclo (-D-TrpD-Asp-Pro-D-Val-Leu-)), in which these antagonists did not fully antagonize the vascular smooth muscle contractions induced by endothelins. Similar proposals have also been made based on experiments using selective $E T_{B}$ receptor agonists such as IRL1620 (Suc-[Glu $\left.{ }^{9}, \mathrm{Ala}^{11,15}\right] \mathrm{ET}$ $1(8-21))(15)$ and sarafotoxin $6 \mathrm{c}(\mathrm{S} 6 \mathrm{c})(16,17)$.

For further definitive pharmacological confirmation of the receptor subtypes on the vascular smooth muscle cells, effects of $\mathrm{ET}_{\mathrm{B}}$-receptor antagonists should be examined. IRL1038 is a selective $\mathrm{ET}_{\mathrm{B}}$-receptor antagonist 
and is known to be effective in antagonizing the $\mathrm{ET}_{\mathrm{B}}$ receptor-mediated vasodilation $(14,18)$. A study using this antagonist in swine pulmonary blood vessels, however, revealed that the contractile responses induced by some $\mathrm{ET}_{\mathrm{B}^{-}}$ receptor agonists cannot be inhibited by IRL1038. This observation suggests that the IRL1038-insensitive $E T_{B}$ receptor that mediates contraction is different from the IRL1038-sensitive $\mathrm{ET}_{\mathrm{B}}$ receptor that mediates endothelium-dependent relaxation (14).

Coexistence of both $\mathrm{ET}_{\mathrm{A}}$ and $\mathrm{ET}_{\mathrm{B}}$ receptors on the same vascular smooth muscle may complicate pharmacological analysis of receptor subtypes. If only typical $\mathrm{ET}_{\mathrm{A}}$ and typical $\mathrm{ET}_{\mathrm{B}}$ receptors are colocalized, a nonselective $\mathrm{ET}_{\mathrm{A}} / \mathrm{ET}_{\mathrm{B}}$-receptor antagonist is expected to be effective in antagonizing endothelin-induced contraction of such smooth muscles. However, Warner and colleagues, who investigated effects of an $E T_{A} / E T_{B}$-receptor antagonist, PD142893 (Ac-D-Dip-Leu-Asp-Ile-Ile-Trp) (19), on the rabbit pulmonary artery, rat stomach strip and the rat perfused mesentery again revealed receptor heterogeneity among the $\mathrm{ET}_{\mathrm{B}}$ receptors (20). Therefore, in the present study, we investigated the effects of PD142893 on the contractions induced by some endothelin receptor agonists in the isolated rabbit lateral saphenous vein and compared them with those in the saphenous artery, in order to characterize the endothelin receptor subtypes involved in endothelin-induced contractions of venous smooth muscle.

\section{MATERIALS AND METHODS}

\section{Tissue preparation}

The lateral saphenous veins or the saphenous arteries were removed from male Japan White rabbits (2.4-3.0 kg body weight; Funabashi Farm, Funabashi) anesthetized with pentobarbital sodium $(50 \mathrm{mg} / \mathrm{kg}$, i.v.). After careful dissection to remove the connective tissue from the isolated blood vessels in a cold modified Krebs-Ringer bicarbonate solution, they were divided into rings of $2-3$ $\mathrm{mm}$ in length. The vascular endothelium was removed by gentle mechanical rubbing of the internal surface. Each ring preparation was then mounted horizontally between two stainless steel hooks in an organ chamber filled with $5 \mathrm{ml}$ of the modified Krebs-Ringer bicarbonate solution. One hook was connected to a micrometer for controlling the tissue length and the other, to a force transducer (TB612T; Nihon Kohden, Tokyo) for isometric force recording. The modified Krebs-Ringer bicarbonate solution was aerated constantly with a $95 \% \mathrm{O}_{2}$ and $5 \% \mathrm{CO}_{2}$ gas mixture and maintained at $37^{\circ} \mathrm{C}$. The endothelium removal of each ring was verified by the absence of a relaxant response to acetylcholine $(1 \mu \mathrm{M})$ in the rings precontracted with phenylephrine $(1-3 \mu \mathrm{M})$.

\section{Experimental procedures}

During an initial equilibration period of $60 \mathrm{~min}$, rings of the saphenous arteries and the lateral saphenous veins were stretched by resting loads of $0.8 \mathrm{~g}$ and $0.2 \mathrm{~g}$, respectively. Then the contractility of each preparation was examined by increasing the $\mathrm{KCl}$ concentration in the bathing medium (final concentration of $60 \mathrm{mM}$ for the saphenous artery and $100 \mathrm{mM}$ for the saphenous vein). Such $\mathrm{K}^{+}$ deporalization was repeated at intervals of 30-40 min until the contractile response attained a steady state (usually 3-4 times). Cumulative concentration-response curves for endothelin or sarafotoxin peptides were then constructed by increasing the concentration in the organ chamber in half-log increments. Contractile responses induced by these agonists were expressed as percents of the above-mentioned maximal response to $\mathrm{KCl}$. When the effects of BQ-123 and PD142893 were examined, each compound was added to the organ chamber 15-20 min before addition of the first dose of the agonists, and appropriate parallel control experiments were carried out with the vehicle alone. When ethanol, methanol or DMSO was used as a solvent, their final concentrations did not exceed $0.3 \%, 1.0 \%$ or $0.5 \%$, respectively; and they showed no significant influence on the contractile responses in the present experiments.

\section{Drugs and solutions}

The composition of the modified Krebs-Ringer bicarbonate solution used in the present study was as follows: $118.4 \mathrm{mM} \mathrm{NaCl}, 4.7 \mathrm{mM} \mathrm{KCl}, 1.2 \mathrm{mM} \mathrm{MgSO}_{4}, 1.9 \mathrm{mM}$ $\mathrm{CaCl}_{2}, 1.2 \mathrm{mM} \mathrm{KH}_{2} \mathrm{PO}_{4}, 10.1 \mathrm{mM}$ glucose and $25.0 \mathrm{mM}$ $\mathrm{NaHCO}_{3}$. ET-1, ET-2, ET-3 and S6c were purchased from Peptide Institute, Inc. (Osaka). The selective $\mathrm{ET}_{\mathrm{B}}$ receptor agonist [Glu $\mathrm{G}^{9}$ sarafotoxin $6 \mathrm{~b}\left(\left[\mathrm{Glu} \mathbf{u}^{9}\right] \mathrm{S} 6 \mathrm{~b}\right)$ was synthesized as reported previously (21). These peptides were dissolved in phosphate-buffered saline ( $\mathrm{pH} \mathrm{7.2)} \mathrm{contain-}$ ing $0.05 \%$ bovine serum albumin. IRL1620 was synthesized at International Research Laboratories, Ciba-Geigy Japan (Takarazuka), as reported previously (15), and dissolved in $0.01 \mathrm{~N} \mathrm{NaOH}$. BQ-123 was purchased from Peninsula Laboratories, Inc. (Belmont, CA, USA) and dissolved in absolute ethanol. PD142893 was synthesized at Research Laboratories, Nippon Chemiphar Co., Ltd. (Misato) and dissolved in absolute methanol. The other drugs used were: phenylephrine hydrochloride, acetylcholine chloride, pyrilamine maleate, indomethacin, nordihydroguaiaretic acid (Sigma, St. Louis, MO, USA), atropine sulfate (Nacalai Tesque, Kyoto), phentolamine mesylate (Ciba-Geigy Japan), guanethidine sulfate (Tokyo Kasei, Tokyo) and methysergide hydrogenmaleinate (Sandoz, Basel, Switzerland). Indomethacin was dissolved in absolute ethanol and nordihydroguaiaretic acid was dissolved in $50 \%$ DMSO. The other drugs were dis- 

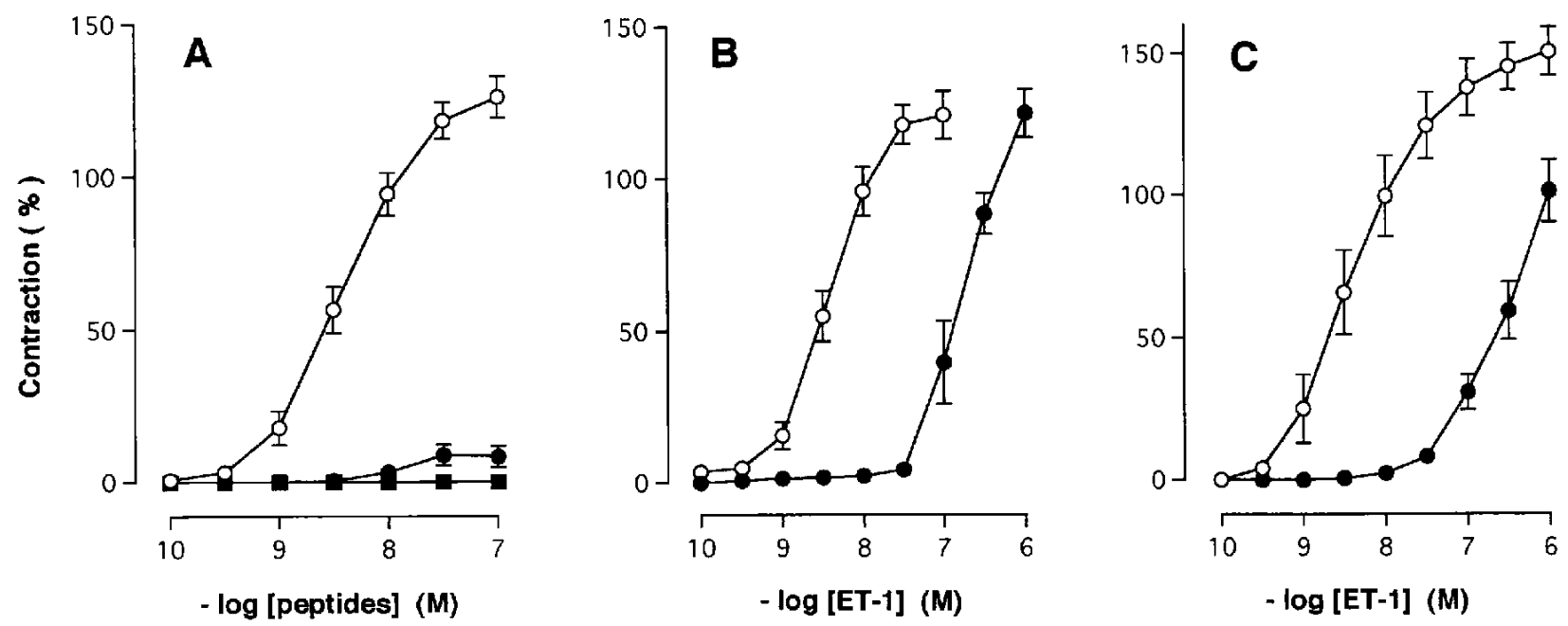

Fig. 1. Contractile responses to endothelin-1 (ET-1), sarafotoxin 6c (S6c) and IRL1620 and effects of BQ-123 and PD142893 on the ET-1-induced contraction in isolated rabbit saphenous artery. A: Concentration-response curves for ET-1 ( $)$, IRL1620 (O) and S6c ( $)$. B: Concentration-response curves for ET-1 in the absence (O) and presence (O) of $3 \mu \mathrm{M}$ BQ-123. C: Concentration-response curves for ET-1 in the absence ( $)$ and presence (O) of $3 \mu \mathrm{M}$ PD142893. Contractile responses are expressed as percentages of the maximal tension induced by $60 \mathrm{mM} \mathrm{KCl}$. Bars represent \pm S.E.M. $(n=5-8)$.

solved in distilled water.

\section{Analyses of the data}

Concentration-response curves for the agonists were analysed by means of a curve-fitting computer program. Maximal responses $\left(\mathrm{E}_{\max }\right)$ and the $\mathrm{EC}_{50}$ values are expressed as the means \pm S.E.M. The data were statistically evaluated by Student's $t$-test. Values were considered to differ significantly when the probability values were less than 0.05 .

\section{RESULTS}

\section{Effects of ET-1, IRL1620 and S6c on the saphenous ar-} tery

ET-1 $(0.1-100 \mathrm{nM})$ elicited concentration-dependent contraction of the saphenous artery. In contrast, one of the $\mathrm{ET}_{\mathrm{B}}$-receptor agonist, IRL1620 (up to $1 \mu \mathrm{M}$ ), caused only very weak contraction and the other $\mathrm{ET}_{\mathrm{B}}$-receptor agonist, S6c (up to $1 \mu \mathrm{M}$ ), showed no effect at all (Fig. 1A). The ET-1-induced responses were clearly shifted in parallel to the right by the $\mathrm{ET}_{\mathrm{A}}$-receptor antagonist BQ-123 $(3 \mu \mathrm{M})$ and the $\mathrm{ET}_{\mathrm{A}} / \mathrm{ET}_{\mathrm{B}}$-receptor antagonist PD142893 $(3 \mu \mathrm{M})$ without any reduction in the maximal responses (Fig. 1 and Table 1). These concentrations of BQ-123 and PD142893 alone produced no mechanical response in the isolated saphenous artery.

Vasoconstrictor responses induced by ET-1 and related peptides in the saphenous vein and effects of $B Q-123$

ET-1 and IRL1620 produced strong concentration- dependent contractions of the lateral saphenous vein and were almost equipotent in this tissue (Table 2). These contractile responses were resistant to the following agents: the muscarinic antagonist atropine $(5 \mu \mathrm{M})$, the $\alpha$-adrenoceptor antagonist phentolamine $(10 \mu \mathrm{M})$, the adrenergic neuron blocking agent guanethidine $(1 t \mathrm{M})$, the histamine $\mathrm{H}_{1}$-receptor antagonist pyrilamine $(0.3$ $\mu \mathrm{M})$, the 5-HT-receptor antagonist methysergide (10 $\left.{ }_{\mu} \mathrm{M}\right)$, the cyclooxygenase inhibitor indomethacin $(10 \mu \mathrm{M})$ and the lipoxygenase inhibitor nordihydroguaiaretic acid

Table 1. Effects of $\mathrm{BQ}-123$ and PD142893 on the $\mathrm{EC}_{50}$ values and maximal responses for endothelin-1 (ET-1) in isolated rabbit saphenous artery

\begin{tabular}{lccc}
\hline & $\mathrm{n}$ & $\mathrm{EC}_{50}(\mathrm{nM})$ & $\mathrm{E}_{\max }(\%)$ \\
\hline Without BQ-123 & 8 & $\begin{array}{c}3.95 \\
(2.42-6.47)\end{array}$ & $124.7 \pm 7.3$ \\
With BQ-123 $(3 \mu \mathrm{M})$ & 5 & $\begin{array}{c}163^{\mathrm{a}} \\
(64.3-327)\end{array}$ & $123.0 \pm 7.9$ \\
Without PD142893 & 5 & $\begin{array}{c}4.86 \\
(1.38-17.2)\end{array}$ & $150.6 \pm 8.2$ \\
With PD142893 $(3 \mu \mathrm{M})$ & 5 & $(197-1310)$ & N.E. \\
\hline
\end{tabular}

Values are expressed as the means \pm S.E.M. $n$ : number of experiments. $E_{\max }$ : maximal responses, expressed as percentages of the maximal tension induced by $60 \mathrm{mM} \mathrm{KCl}$. The $95 \%$ confidence limits are given in parentheses under the $\mathrm{EC}_{50}$ values. N.E.: not evaluated, because the responses did not reach a maximum even at the highest concentration tested. ${ }^{\mathrm{a}} \mathrm{P}<0.05$, compared with the control value without BQ-123 or PD142893. 'The value was calculated by assuming that the $E_{\max }$ in the presence of PD142893 was the same as the control value. 
Table 2. Effects of BQ-123 on the $\mathrm{EC}_{50}$ values and maximal responses for endothelin-1 (ET-1) and related peptides in rabbit lateral saphenous vein

\begin{tabular}{|c|c|c|c|c|c|c|}
\hline & \multicolumn{3}{|c|}{ Control } & \multicolumn{3}{|c|}{ With BQ-123 $(3 \mu \mathrm{M})$} \\
\hline & $\mathbf{n}$ & $\mathrm{EC}_{50}(\mathrm{nM})$ & $\mathrm{E}_{\max }(\%)$ & $\mathrm{n}$ & $\mathrm{EC}_{50}(\mathrm{nM})$ & $E_{\max }(\%)$ \\
\hline ET-1 & 5 & $\begin{array}{c}2.36 \\
(1.38-4.01)\end{array}$ & $167.9 \pm 8.8$ & 5 & $\begin{array}{c}2.39 \\
(1.93-2.95)\end{array}$ & $185.4 \pm 15.5$ \\
\hline ET-3 & 6 & $\begin{array}{c}1.07 \\
(0.80-1.44)\end{array}$ & $119.0 \pm 5.4$ & 6 & $\begin{array}{c}1.01 \\
(0.58-1.75)\end{array}$ & $126.4 \pm 3.2$ \\
\hline IRL 1620 & 5 & $\begin{array}{c}2.72 \\
(1.53-4.84)\end{array}$ & $192.0 \pm 15.7$ & 6 & $\begin{array}{c}1.81 \\
(1.22-2.68)\end{array}$ & $188.1 \pm 5.4$ \\
\hline$S 6 c$ & 5 & $\begin{array}{c}0.98 \\
(0.71-1.35)\end{array}$ & $146.5+3.6$ & 5 & $\begin{array}{c}0.93 \\
(0.72-1.20)\end{array}$ & $144.9 \pm 4.1$ \\
\hline$\left[\mathrm{Glu}^{9}\right] \mathrm{S} 6 \mathrm{~b}$ & 5 & $\begin{array}{c}0.67 \\
(0.38-1.18)\end{array}$ & $123.9 \pm 6.0$ & 6 & $\begin{array}{c}0.52 \\
(0.37-0.73)\end{array}$ & $118.0 \pm 4.0$ \\
\hline
\end{tabular}

Values are expressed as the means \pm S.E.M. $n$ : number of experiments. $E_{\max }$ : maximal responses, expressed as percentages of the maximal tension induced by $100 \mathrm{mM} \mathrm{KCl}$. The $95 \%$ confidence limits are given in parentheses under the $\mathrm{EC}_{50}$ values. $\mathrm{S} 6 \mathrm{c}$ : sarafotoxin $6 \mathrm{c}$, [Glu $\left.{ }^{9}\right] \mathrm{S} 6 \mathrm{~b}$ : [Glu $\left.{ }^{9}\right]$ sarafotoxin $6 \mathrm{~b}$.

$(10 \mu \mathrm{M})$ (data not shown).

ET-3 and selective ET $_{\mathrm{B}}$-receptor agonists, S6c and $\left[\mathrm{Glu}^{9}\right] \mathrm{S} 6 \mathrm{~b}$ (22), also elicited concentration-dependent contractions of this venous smooth muscle. The $\mathrm{EC}_{50}$ values for these sarafotoxins were slightly lower than that for ET-1 (Table 2). In contrast to the antagonistic effect observed in the saphenous artery, BQ-123 $(3 \mu \mathrm{M})$ did not affect any of the concentration-response curves of these endothelins and related peptides in the saphenous vein (Fig. 2 and Table 2). The $\mathrm{EC}_{50}$ values were almost identi$\mathrm{cal}$ in the absence or presence of BQ-123.
Effects of PDI42893 on vasoconstrictor responses induced by $E T-1$ and related peptides in the saphenous vein

When the venous ring preparations were pretreated with $10 \mu \mathrm{M}$ of PD142893, the IRL1620-induced responses were greatly shifted in parallel to the right (Fig. 3B and Table 3). This antagonist alone had no mechanical effect. In contrast to the IRL1620-induced responses, the ET-1induced concentration-response curve was not affected at all by the same concentration of PD142893 (Fig. 3A). The $\mathrm{EC}_{50}$ value for ET-1 obtained in the presence of PD142893 was not different from that in the absence of
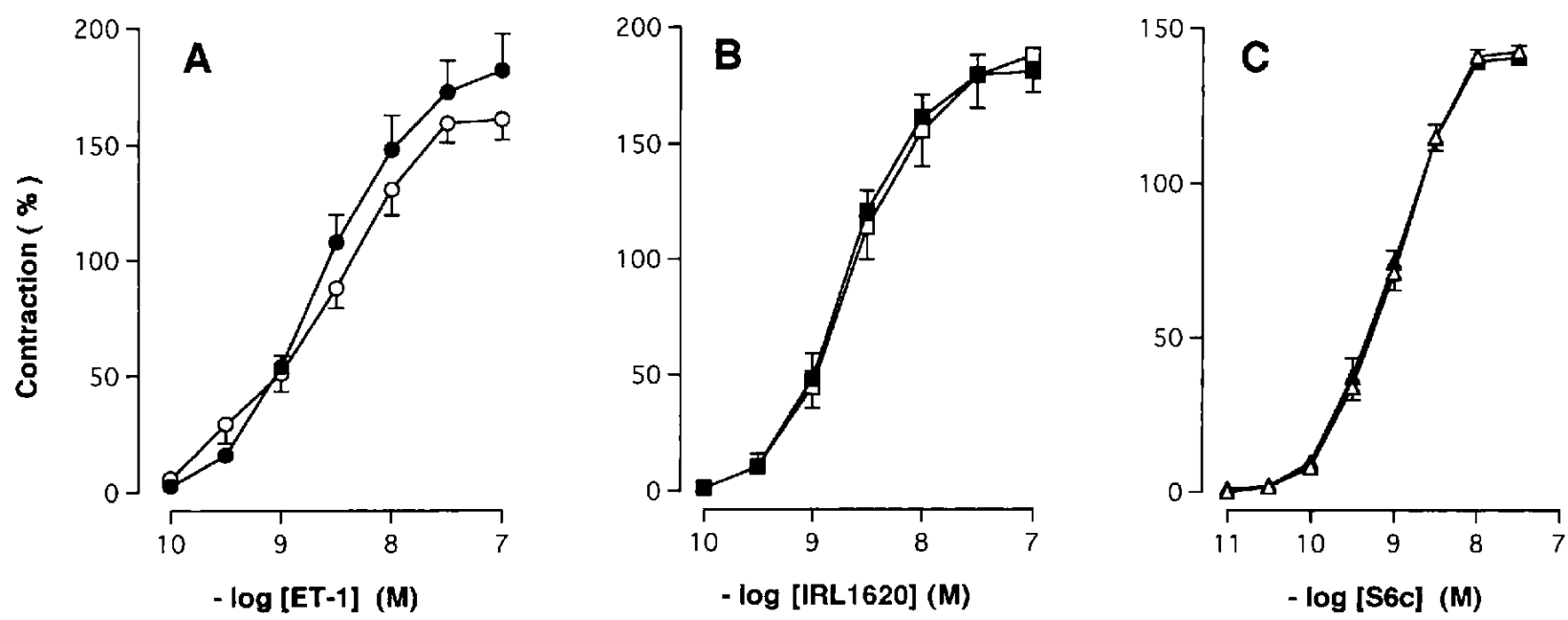

Fig. 2. Effects of $3 \mu \mathrm{M}$ BQ-123 on the contractile responses induced by endothelin-1 (ET-1), IRL1620 and sarafotoxin 6c (S6c) in isolated rabbit lateral saphenous vein. A: Concentration-response curves for ET-1 in the absence ( $O$ ) and presence (O) of BQ-123. B: Similar curves for IRL1620 in the absence ( $\square$ ) and presence ( $\square$ ) of BQ-123. C: Similar curves for S6c in the absence $(\triangle)$ and presence $(A)$ of BQ-123. Contractile responses are expressed as percentages of the maximal tension induced by $100 \mathrm{mM}$ KCl. Bars represent \pm S.E.M. $(n=5-6)$. 
Table 3. Effects of PD142893 on the $E C_{50}$ values and maximal responses for endothelin-1 (ET-1) and related peptides in isolated rabbit saphenous vein

\begin{tabular}{|c|c|c|c|c|c|c|}
\hline & \multicolumn{3}{|c|}{ Control } & \multicolumn{3}{|c|}{ With PD142893 $(10 \mu \mathrm{M})$} \\
\hline & $\mathrm{n}$ & $\mathrm{EC}_{50}(\mathrm{nM})$ & $E_{\max }(\%)$ & n & $\mathrm{EC}_{30}(\mathrm{nM})$ & $E_{\max }(\%)$ \\
\hline ET-1 & 6 & $\begin{array}{c}1.64 \\
(1.19-2.26)\end{array}$ & $186.5 \pm 10.1$ & 7 & $\begin{array}{c}1.43 \\
(0.99-2.05)\end{array}$ & $180.3 \pm 6.0$ \\
\hline ET-3 & 6 & $\begin{array}{c}1.07 \\
(0.80-1.43)\end{array}$ & $121.6 \pm 5.9$ & 5 & $\begin{array}{c}2.75^{\mathrm{a}} \\
(1.25-6.04)\end{array}$ & $151.3 \pm 8.6^{\mathrm{a}}$ \\
\hline IRL1620 & 5 & $\begin{array}{c}2.24 \\
(1.75-2.88)\end{array}$ & $149.3 \pm 12.2$ & 6 & $\begin{array}{c}123^{\mathrm{a}, \mathrm{b}} \\
(96.4-157)\end{array}$ & N.E. \\
\hline S6c & 5 & $\begin{array}{c}0.38 \\
(0.25-0.57)\end{array}$ & $169.4 \pm 7.3$ & 9 & $\begin{array}{c}3.02^{\mathrm{a}} \\
(2.00-4.57)\end{array}$ & $187.1 \pm 9.8$ \\
\hline$\left[\mathrm{Glu}^{9}\right] \mathrm{S} 6 \mathrm{~b}$ & 6 & $\begin{array}{c}0.44 \\
(0.29-0.66)\end{array}$ & $133.9 \pm 5.4$ & 5 & $\begin{array}{c}1.39^{\mathrm{a}} \\
(0.95-2.03)\end{array}$ & $158.4 \pm 5.1^{\mathrm{a}}$ \\
\hline
\end{tabular}

Values are expressed as the means \pm S.E.M. $n$ : number of experiments. $E_{\max }$ : maximal responses, expressed as percentages of the maximal tension induced by $100 \mathrm{mM} \mathrm{KCl}$. The $95 \%$ confidence limits are given in parentheses under the $\mathrm{EC}_{50}$ values. N.E.: not evaluated, because the responses did not reach the maximum even at the highest concentration tested. ${ }^{a} \mathrm{P}<0.05$, compared with the control value. ${ }^{6}$ The value was calculated by taking the value at $1 \mu \mathrm{M}$ of IRL1620 as the $\mathrm{E}_{\max }$. S6c: sarafotoxin $6 \mathrm{c}$, [Glu']S6b: [Glu $\left.{ }^{9}\right]$ sarafotoxin $6 b$.

this antagonist (Table 3 ).

In the cases of ET-3, S6c and [Glu']S6b, their concentration-response curves shifted to the right by PD142893 $(10 \mu \mathrm{M})$, but their rightward shifts were much less compared with that in the case of IRL1620, and their maximal responses were increased (Fig. 4 and Table 3). An increased concentration $(30 \mu \mathrm{M})$ of PD142893 could not cause any further rightward shift of the concentrationresponse curve for S6c (Fig. 5B). In contrast, 1.0-30 $\mu \mathrm{M}$ of PD142893 showed potent antagonistic effects on the IRL1620-induced contraction in a dose-dependent manner (Fig. 5A). In the presence of $30 \mu \mathrm{M}$ of PD142893, $1 \mu \mathrm{M}$ of IRL1620 could elicit only very weak contraction (less than $20 \%$ of $\mathrm{KCl}$ contraction), but the same preparations showed full responses, if $100 \mathrm{nM}$ of $\mathrm{S} 6 \mathrm{c}$ was added (data not shown).

Furthermore, the effect of combination of BQ-123 ( $3 \mu \mathrm{M})$ and PD142893 $(10 \mu \mathrm{M})$ on ET-1-induced response in the saphenous vein was not different from that of PD142893 alone (data not shown).
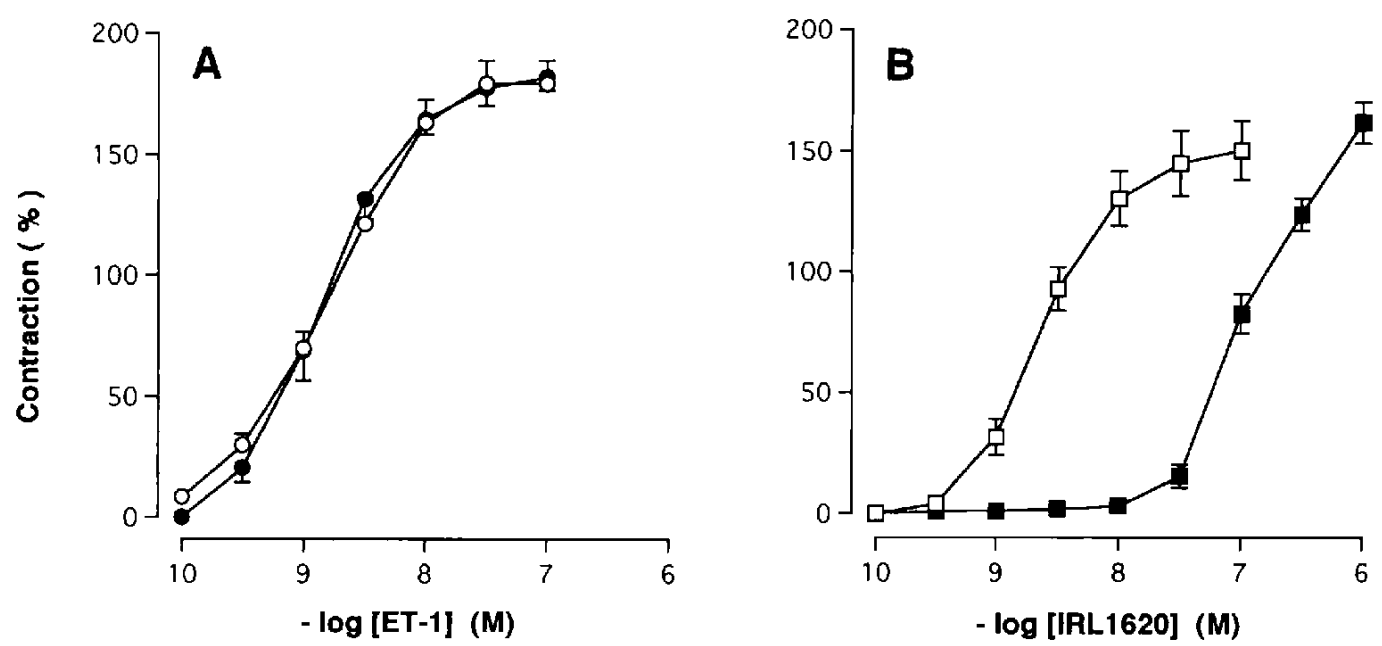

Fig. 3. Effects of $10 \mu \mathrm{M}$ PD142893 on the contractile responses induced by endothelin-1 (ET-1) or IRL1620 in isolated rabbit saphenous vein. A: Concentration-response curves for ET-1 in the absence $(O)$ and presence (O) of PD142893. B: Similar curves for IRL1620 in the absence $(\square)$ and presence $(\square)$ of PD 142893. Contractile responses are expressed as percentages of the maximal tension induced by $100 \mathrm{mM} \mathrm{KCl}$. Bars represent \pm S.E.M. $(\mathrm{n}=5-7)$. 

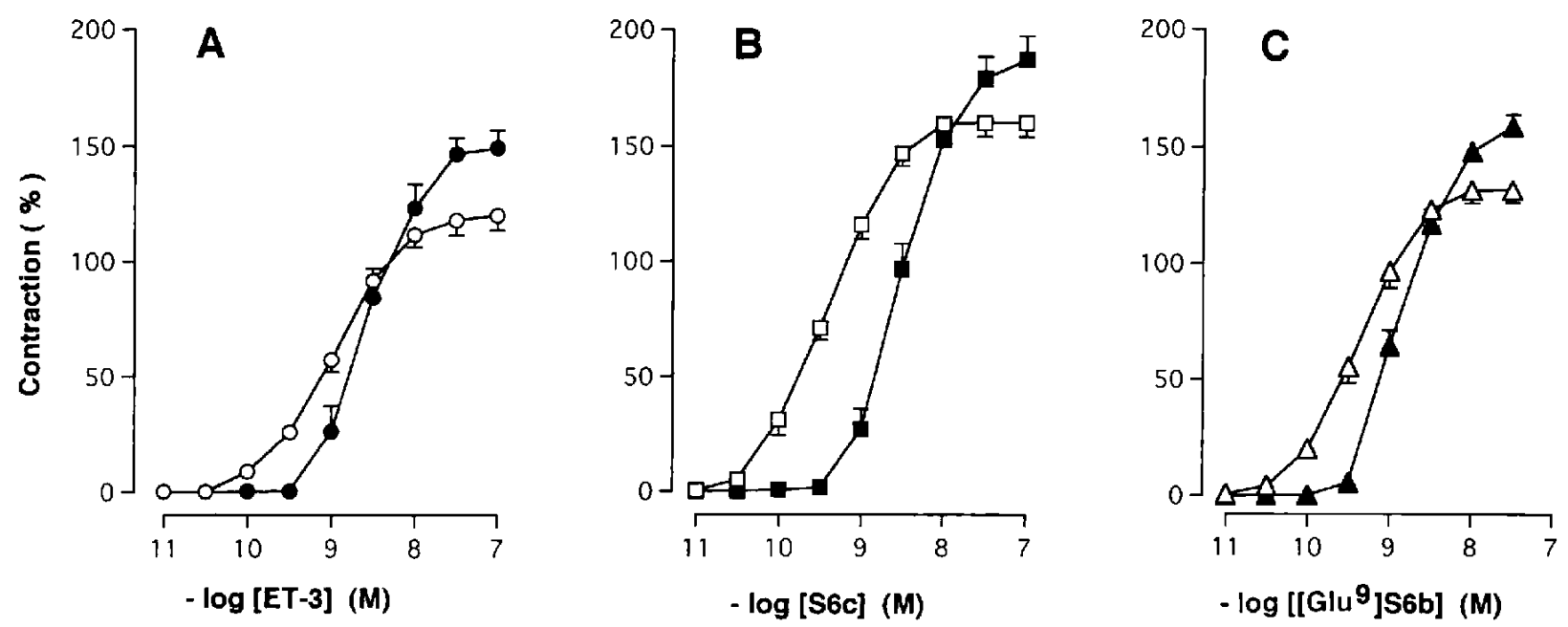

Fig. 4. Effects of $10 \mu \mathrm{M}$ PD142893 on the contractile responses induced by endothelin-3 (ET-3), sarafotoxin $6 \mathrm{c}$ (S6c) or [Glu ${ }^{9}$ sarafotoxin $6 \mathrm{~b}\left(\left[\mathrm{Glu}^{9}\right] \mathrm{S} 6 \mathrm{~b}\right)$ in isolated rabbit saphenous vein. A: Concentration-response curves for ET-3 in the absence (O) and presence ( $O$ ) of PD 142893. B: Similar curves for S6c in the absence ( $\square$ ) and presence ( $\square$ ) of PDI42893. C: Similar curves for $\left[G u^{9}\right] \mathrm{S} 6 \mathrm{~b}$ in the absence $(\triangle)$ and presence $(\Delta)$ of PD142893. Contractile responses are expressed as percentages of the maximal tension induced by $100 \mathrm{mM} \mathrm{KCl}$. Bars represent \pm S.E.M. $(n=5-6)$.
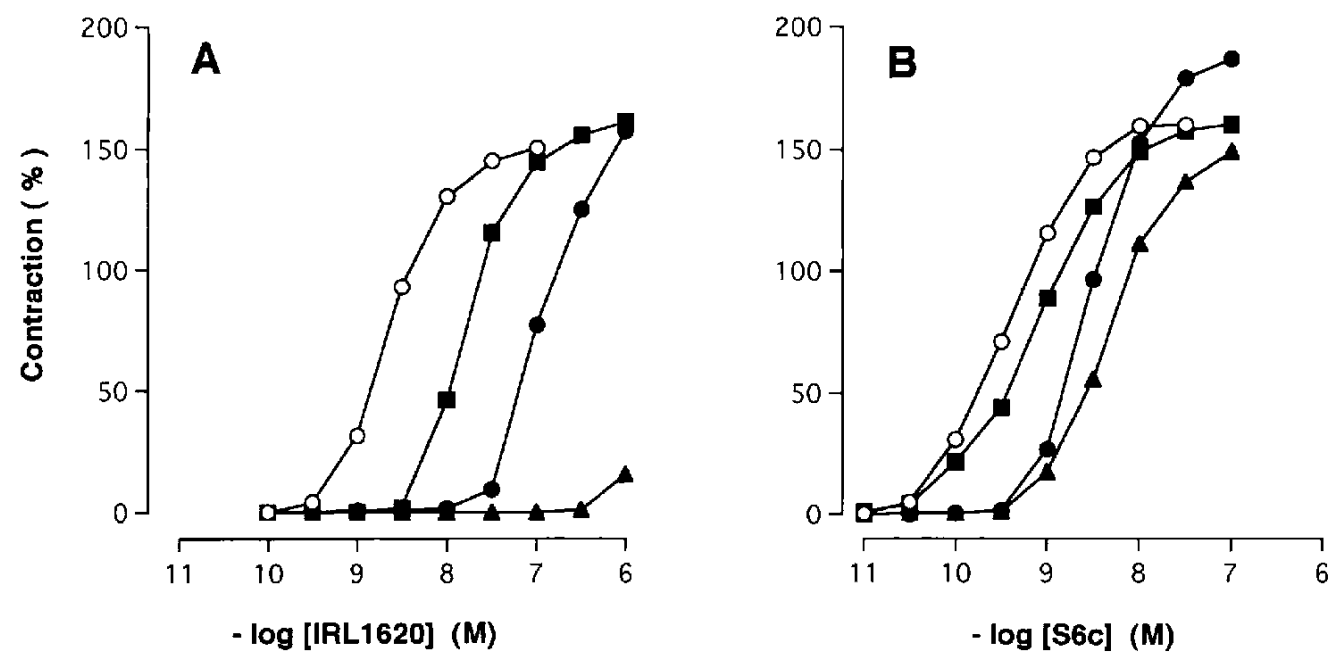

Fig. 5. Effects of various concentrations of PD142893 on the contractile responses induced by IRLl620 and sarafotoxin $6 \mathrm{c}$ (S6c) in isolated rabbit saphenous vein. A: Concentration-response curves for IRL1620 in the absence ( $)$ ) and presence of $3 \mu \mathrm{M}$ ( $\square), 10 \mu \mathrm{M}(\mathbf{O})$ or $30 \mu \mathrm{M}(\mathbf{A})$ of PD142893. B: Similar curves for S6c in the absence ( ) and presence of $3 \mu \mathrm{M}(\square), 10 \mu \mathrm{M}(\mathbf{O})$ or $30 \ell \mathrm{M}(\mathbf{\Delta})$ of PD142893. Contractile responses are expressed as percentages of the maximal tension induced by $100 \mathrm{mM} \mathrm{KCl}$. Each value indicates the mean of $3-6$ experiments.

\section{DISCUSSION}

In the present experiments, ET-1 caused strong contractile responses in the isolated saphenous artery in a concentration-dependent manner, while $\mathrm{ET}_{\mathrm{B}}$-receptor agonists, IRL1620 and S6c, had practically no effect in this tissue. Moreover, the ET-1-induced concentration-response curve for the saphenous artery shifted in parallel to the right by the $\mathrm{ET}_{\mathrm{A}}$-receptor antagonist $\mathrm{BQ}-123$ and the $\mathrm{ET}_{\mathrm{A}} / \mathrm{ET}_{\mathrm{B}}$ antagonist PD142893 (Fig. 1). These results sug- gest that the rabbit saphenous artery is dominated by $\mathrm{ET}_{\mathrm{A}}$ receptors. This is in agreement with a previous general assumption that vascular smooth muscle cells contain predominantly $\mathrm{ET}_{\mathrm{A}}$ receptors.

In the saphenous vein, however, BQ-123 could not alter the ET-1-induced contractile responses, and all of the $\mathrm{ET}_{\mathrm{B}}$ receptor agonists were shown to be as potent as ET-1 as vasoconstrictor agents (Fig. 2 and Table 2). These observations indicate that the $\mathrm{ET}_{\mathrm{B}}$ receptor on the smooth muscle of rabbit saphenous vein mediates vasoconstric- 
tion, as reported previously (10).

The antagonistic effect of PD142893 on both $\mathrm{ET}_{\mathrm{A}}$ and $\mathrm{ET}_{\mathrm{B}}$ receptors was confirmed in the present study, because, as mentioned above, the rightward shift of the ET-1-induced concentration-response curve for the saphenous artery may be explained by its antagonistic effect on $\mathrm{ET}_{\mathrm{A}}$ receptors (Fig. 1); and the similar effect on IRL1620-induced contraction of the saphenous vein may be attributable to its effect on $\mathrm{ET}_{\mathrm{B}}$ receptors (Fig. 3B).

Nevertheless, PD142893 could not affect the ET-1-induced contractile response of the saphenous vein at all (Fig. 3A). The concentration-response curves for ET-3 and $\mathrm{ET}_{\mathrm{B}}$-receptor-selective sarafotoxins, $\mathrm{S} 6 \mathrm{c}$ and $\left[\mathrm{Glu}^{9}\right]$ S6b, were slightly shifted to the right by $10 \mu \mathrm{M}$ of PD142893 (Fig. 4), but further increasing the concentration of PD142893 (30 $\mu \mathrm{M})$ could not cause any additional shift of the concentration-response curve of S6c, in marked contrast to the very potent antagonistic effect of the same high concentration of PD142893 on the IRL1620-induced contraction in this vein (Fig. 5). The most simple explanation for these apparent contradictory results may be to assume the existence of two distinct $\mathrm{ET}_{\mathrm{B}}$-receptor subtypes; namely, PD142893-sensitive and PD142893-insensitive $\mathrm{ET}_{\mathrm{B}}$ receptors. If so, IRL1620 can be considered to act mainly on the PD142893-sensitive subtype, whereas the PD142893-insensitive subtype is considered to be responsible for the effects of ET-1, ET-3, $\mathrm{S} 6 \mathrm{c}$ and $\left[\mathrm{Glu}^{9}\right] \mathrm{S} 6 \mathrm{~b}$. The similar results have also been obtained in our laboratory by using another $\mathrm{ET}_{\mathrm{A}} / \mathrm{ET}_{\mathrm{B}}$ antagonist, Ro46-2005, which showed a marked inhibitory effect on IRL1620-induced contraction of the rabbit saphenous vein, in contrast with very weak or no antagonistic effects on ET-1-, ET-3- and S6c-induced responses (unpublished data). These observations also suggest that rabbit saphenous vein contains two different $\mathrm{ET}_{\mathrm{B}}$-receptor subtypes.

Some of the recent studies have demonstrated that

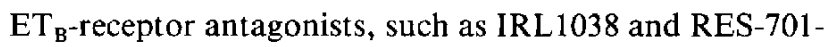
1, as well as an $\mathrm{ET}_{\mathrm{A}} / \mathrm{ET}_{\mathrm{B}}$ antagonist, PD142893, are ineffective in antagonizing $\mathrm{ET}_{\mathrm{B}}$-receptor-mediated contractile response of some vascular smooth muscles, in spite of their potent antagonistic effect on $\mathrm{ET}_{\mathrm{B}}$-receptor-mediated vasodilation $(14,20,23)$. Based on the results about the antagonistic potencies of IRL1038 or RES-701-1, it has been proposed that there are two types of $\mathrm{ET}_{\mathrm{B}}$ receptors: an $\mathrm{ET}_{\mathrm{B}}$-receptor subtype that is sensitive to these antagonists, termed $\mathrm{ET}_{\mathrm{B} 1}$, and another subtype that is insensitive to them, termed $\mathrm{ET}_{\mathrm{B} 2}$ (23). Applying these considerations to the present results, PD142893-sensitive and insensitive subtypes could be named $\mathrm{ET}_{\mathrm{B} 1}$ and $\mathrm{ET}_{\mathrm{B} 2}$, respectively.

ET-1 and IRL1620 are known to produce vasodilation by the release of $\operatorname{EDRF}(7,24)$, and it has been reported that the specific binding of [ ${ }^{125}$ I]IRL 1620 to porcine lung membranes could be displaced by ET-1 (25). Considering that IRL1620 is an $\mathrm{ET}_{\mathrm{B} 1}$ agonist, as mentioned above, these findings suggest that ET-1 may act also on $\mathrm{ET}_{\mathrm{BI}}$ receptors as an agonist. Therefore, it is likely that ET-1 is a potent agonist for all the types of endothelin receptors, $\mathrm{ET}_{\mathrm{A}}, \mathrm{ET}_{\mathrm{B} 1}$ and $\mathrm{ET}_{\mathrm{B} 2}$. Although ET-1-induced contraction was not shifted by PD142893 in the rabbit saphenous vein and mediated by the $\mathrm{ET}_{\mathrm{B} 2}$ receptor, it cannot be ruled out that $\mathrm{ET}_{\mathrm{A}}$ and $\mathrm{ET}_{\mathrm{B} 1}$ receptors on the saphenous vein also contribute to the contractile response, because it is pos-

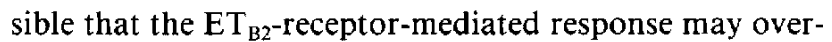
lap with the responses mediated by $\mathrm{ET}_{\mathrm{A}^{-}}$and/or $\mathrm{ET}_{\mathrm{B1}^{-}}$ receptor subtypes.

From a binding study, it has been reported that the endothelin receptor population in the rabbit saphenous vein is made up of $\mathrm{ET}_{\mathrm{A}}$ receptors (about 70\%) and non-ET receptors (about $30 \%$ ) and that the latter contains two components, one of which displays very high affinity for ET-3 and moderate affinity for S6c (26). These findings seem to support our present study, because there is a possibility that the two components of non-ET $\mathrm{A}_{\mathrm{A}}$ receptors in this smooth muscle correspond to $\mathrm{ET}_{\mathrm{B} 1}$ and $\mathrm{ET}_{\mathrm{B} 2}$, although the relative functional contribution of $\mathrm{ET}_{\mathrm{A}}$ and the two $\mathrm{ET}_{\mathrm{B}}$-receptor subtypes in this vasculature cannot be assessed from the present experiment.

In spite of the accumulation of pharmacological evidence for the existence of additional endothelin receptor subtypes, only two endothelin receptors, $\mathrm{ET}_{\mathrm{A}}$ and $\mathrm{ET}_{\mathrm{B}}$, have been so far cloned $(3-5)$. If there is no other endothelin receptor subtype, an alternative explanation is necessary to account for the results obtained in this study. Since IRL1620 is known to be a highly reversible ligand for the $\mathrm{ET}_{\mathrm{B}}$ receptor (25), it is possible that this selective ligand is more easily antagonized than ET-1, a ligand that binds almost irreversibly to the receptor (27). However, PD142893 has been reported to antagonize endotheliumdependent vasodilations induced by ET- 1 very effectively (20). Therefore, the difference in binding characteristics (association and dissociation) of agonists can not be the only reason for the different sensitivities to PD142893. It is also possible that pharmacological classification of endothelin receptors is influenced by coexistence of both $\mathrm{ET}_{\mathrm{A}}$ and $\mathrm{ET}_{\mathrm{B}}$ receptors on the same cell, involvement of multiple intracellular signal transduction systems and/or their possible unknown interactions. To clarify these problems, further studies will be required.

Although the present study indicated that $\mathrm{ET}_{\mathrm{B}}$-receptor agonists could elicit full contractile responses in the rabbit saphenous vein, the physiological role(s) of these Btype endothelin receptors on the vascular smooth muscle has not yet been elucidated. It is important to clarify their distribution among various blood vessels of different 
animal species. The development of selective $\mathrm{ET}_{\mathbf{B 2}}$-receptor antagonists and further characterization of endothelin receptor subtypes are essential for elucidating the physiological and pathophysiological roles of endothelins.

In conclusion, our present results suggest that the rabbit saphenous vein contains two different $\mathrm{ET}_{\mathrm{B}}$-receptor subtypes, $\mathrm{ET}_{\mathrm{B} 1}$ and $\mathrm{ET}_{\mathrm{B} 2}$, both of which can mediate the vasoconstrictive effects of endothelins, and that the saphenous artery contains predominantly $\mathrm{ET}_{\mathrm{A}}$ receptors.

\section{Acknowledgments}

We thank Mr. Y. Kawasaki, Mr. N. Mochizuki and Dr. S. Masui, Nippon Chemiphar Co., Ltd. for the synthesis and binding assay of PD142893. We are also grateful to Dr. M. Takai, Dr. Y. Urade, Dr. T. Okada and Dr. A.F. James, Ciba-Geigy Japan, for the generous gift of IRL 1620, helpful discussions and critical reading of the manuscript. This work was in part supported by grants for Scientific Research on Priority Areas: "Vascular Endothelium-Smooth Muscle Coupling" from the Ministry of Education, Science and Culture of Japan, Uehara Memorial Foundation and the Fujisawa Foundation.

\section{REFERENCES}

1 Yanagisawa M, Kurihara H, Kimura S, Tomobe Y, Kobayashi M, Mitsui Y, Yazaki Y, Goto K and Masaki T: A novel potent vasoconstrictor peptide produced by vascular endothelial cells. Nature 332, 411 - 415 (1988)

2 Inoue A, Yanagisawa M, Kimura S, Kasuya $\mathrm{Y}$, Miyauchi $\mathrm{T}$, Goto $\mathrm{K}$ and Masaki $\mathrm{T}$ : The human endothelin family: Three structurally and pharmacologically distinct isopeptides predicted by three separate genes. Proc Natl Acad Sci USA 86, 2863-2867 (1989)

3 Masaki T, Vane JR and Vanhoutte M: International union of pharmacology nomenclature of endothelin receptors. Pharmacol Rev 46, $137-142$ (1994)

4 Arai $\mathrm{H}$, Hori S, Aramori I, Ohkubo $\mathrm{H}$ and Nakanishi S: Cloning and expression of a cDNA encoding an endothelin receptor. Nature 348, 730-732 (1990)

5 Sakurai T, Yanagisawa M, Takuwa Y, Miyazaki H, Kimura S, Goto $\mathrm{K}$ and Masaki $\mathrm{T}$ : Cloning of a cDNA encoding a nonisopeptide selective subtype of the endothelin receptor. Nature 348, 732-735 (1990)

6 Masaki T, Kimura S, Yanagisawa $M$ and Goto K: Molecular and cellular mechanism of endothelin regulation. Implication for vascular function. Circulation 84, 1457-1468 (1991)

7 De Nucci G, Thomas GR, D'Orleans-Juste P, Antunes E, Walder CE, Warner TD and Vane JR: The pressor effects of circulating endothelin are limited by its removal in the pulmonary circulation and by release of prostacyclin and endotheliumderived relaxing factor. Proc Natl Acad Sci USA 85, 9797-9800 (1988)

8 Warner TD, Mitchell JA, De Nucci G and Vane JR: Endothelin-1 and endothelin-3 release EDRF from isolated perfused arterial vessels of the rat and the rabbit. J Cardiovasc Pharmacol 13, Supp 5, S85-S88 (1989)

9 Sumner MJ, Cannon TR, Mundin JW, White DG and Watts IS: Endothelin $\mathrm{ET}_{\mathrm{A}}$ and $\mathrm{ET}_{\mathrm{B}}$ receptors mediate vascular smooth muscle contraction. Br I Pharmacol 107, 858-860 (1992)

10 Moreland S, McMullen DM, Delaney CL, Lee VG and Hunt
JT: Venous smooth muscle contains vasoconstrictor $\mathbf{E T}_{\mathrm{B}}$-like receptors. Biochem Biophys Res Commun 184, 100-106 (1992)

11 Clozel M, Grey GA, Breu V, Loeffler B-M and Osterwalder R: The endothelin $\mathbf{E T}_{B}$ receptor mediates both vasodilation and vasoconstriction in vivo. Biochem Biophys Res Commun 186, $867-873$ (1992)

12 Pollack DM and Opgenorth TJ: Evidence for endothelin-induced renal vasoconstriction independent of $E_{A}$ receptor activation. Am J Physiol 264, R222-R226 (1993)

13 Cristol JP, Warner TD, Thiemermann C and Vane JR: Mediation via different receptors of the vasoconstrictor effects of endothelins and sarafotoxins in the systemic circulation and renal vasculature of the anaesthetized rat. $\mathrm{Br} \mathrm{J}$ Pharmacol 108, 776-779 (1993)

14 Sudjarwo SA, Hori M, Takai M, Urade Y, Okada T and Karaki $\mathrm{H}$ : A novel subtype of endothelin B receptor mediating contraction in swine pulmonary vein. Life Sci 53, 431-437 (1993)

15 Takai M, Umemura I, Yamasaki K, Watakabe T, Fujitani Y, Oda $\mathrm{K}$, Urade $Y$, Inui $\mathrm{T}$, Yamamura $\mathrm{T}$ and Okada $\mathrm{T}$ : A potent and specific agonist, Suc-[Glu $\left.{ }^{9}, \mathrm{Ala}^{11,15}\right]$-endothelin-1(8-21), IRL1620, for the $\mathrm{ET}_{\mathrm{B}}$ receptor. Biochem Biophys Res Commun 184, $953-959$ (1992)

16 Takasaki C, Tamiya N, Bdolah V, Wollberg $Z$ and Kochva E: Sarafotoxins S6: several isotoxins from Atractaspis engaddensis (burrowing asp) venom that affect the heart. Toxicon 26, $543-548$ (1988)

17 Williams DL Jr, Jones KL, Pettibone DJ, Lis EV and Clineschmidt BV: Sarafotoxin S6c: an agonist which distinguishes between endothelin receptor subtypes. Biochem Biophys Res Commun 175, 556-561 (1991)

18 Urade Y, Fujitani Y, Oda K, Watakabe T, Umemura I, Takai M, Okada T, Sakata $K$ and Karaki H: An endothelin B receptor-selective antagonist: IRL1038, $\left[\mathrm{Cys}^{11}-\mathrm{Cys}^{15}\right]$ endothelin(11-21). FEBS Lett 311, 12-16 (1992)

19 Cody WL, Doherty AM, He JX, DePue PL, Rapundalo ST, Hingorani GA, Major TC, Panek RL, Dudley DT, Haleen SJ, LaDouceur D, Hill KE, Flynn MA and Reynolds EE: Design of a functional hexapeptide antagonist of endothelin. J Med Chem 35, $3301-3303$ (1992)

20 Warner TD, Allcock GH, Corder R and Vane JR: Use of the endothelin antagonists $\mathrm{BQ}-123$ and PD142893 to reveal three endothelin receptors mediating smooth muscle contraction and the release of EDRF. Br J Pharmacol 110, 777-782 (1993)

21 Takasaki C, Aimoto S, Kitazumi K, Tasaka K, Shiba T, Nishiki K, Furukawa $Y$, Takayanagi $R$, Ohnaka $K$ and Nawata $H$ : Structure-activity relationships of sarafotoxins: chemical synthesis of chimera peptides of sarafotoxins S6b and S6c. Eur J Pharmacol 198, 165-169 (1991)

22 Takayanagi R, Kitazumi K, Takasaki C, Ohnaka K, Aimoto S, Tasaka K, Ohhashi $\mathrm{M}$ and Nawata $\mathrm{H}$ : Presence of non-selective type of endothelin receptor on vascular endothelium and its linkage to vasodilation. FEBS Lett 282, 103-106 (1991)

23 Sudjarwo SA, Hori M, Tanaka T, Matsuda Y, Okada T and Karaki $\mathrm{H}$ : Subtypes of endothelin $\mathrm{ET}_{\mathrm{A}}$ and $\mathrm{ET}_{\mathrm{B}}$ receptors mediating venous smooth muscle contraction. Biochem Biophys Res Commun 200, 627-633 (1994)

24 Karaki H, Sudjarwo SA, Hori M, Takai M, Urade $Y$ and Okada $\mathrm{T}$ : Induction of endothelium-dependent relaxation in the rat aorta by IRL1620, a novel and selective agonist at the endothelin $\mathrm{ET}_{\mathrm{B}}$ receptor. Br J Pharmacol 109, 486-490 (1993) 
25 Watakabe $\mathrm{T}$, Urade $\mathrm{Y}$, Takai $\mathrm{M}$, Umemura I and Okada T: A reversible radioligand specific for the $\mathrm{ET}_{\mathrm{B}}$ receptor: $\left[{ }^{125} \mathrm{I}\right] \mathrm{Tyr}^{13}$ Suc-[Glu $\left.{ }^{9}, \mathrm{Ala}^{11,15}\right]$-endothelin-1(8-21), $\left[{ }^{125}\right.$ I] IRL1620. Biochem Biophys Res Commun 185, 867-873 (1992)

26 Webb ML, Liu ECK, Monshizadegan H, Chao C-C, Lynch J, Fisher SM and Rose PM: Expression of endothelin receptor sub- types in rabbit saphenous vein. Mol Pharmacol 44, 959-965 (1993)

27 Waggoner WG, Genova SL and Rash VA: Kinetic analyses demonstrate that the equilibrium assumption does not apply to ${ }^{[25}$ I] endothelin- 1 binding data. Life Sci 51, $1869-1876$ (1992) 